\title{
Associations between HBeAg status, HBV DNA, ALT level and liver histopathology in patients with chronic hepatitis $B$
}

\author{
Ali Koyuncuer \\ Department of Pathology, Pathologist, Antakya State Hospital, Hatay, Turkey \\ Email address: \\ alikoyuncuer@hotmail.com
}

\section{To cite this article:}

Ali Koyuncuer. Associations between HBeAg Status, HBV DNA, ALT Level and Liver Histopathology in Patients with Chronic Hepatitis B. Science Journal of Clinical Medicine. Vol. 3, No. 6, 2014, pp. 117-123. doi: 10.11648/j.sjcm.20140306.14

\begin{abstract}
Hepatitis B virus (HBV) infection is still a significant healthcare problem all over the world. Between January 2009 and May 2014, a total of 96 patients with chronic hepatitis B (CHB) were enrolled in study. A total of 96 CHB cases were examined. The mean total liver histological activity indices for grade and stage were $6.01 \pm 2.46$, and $1.6 \pm 0.99$ and the mean ALT and AST levels were 32.6 $\pm 21.0 \mathrm{IU} / \mathrm{L}$ and $25.6 \pm 11.2 \mathrm{IU} / \mathrm{L}$, respectively. The mean HBV DNA level was $8.9 \times 106 \pm 3.3106$ IU/mL. Forty (41.7\%) patients had HBV DNA <20 IU/Ml (undetectable) and 14 (14.6\%) patients had HBV DNA levels between 21 and $2000 \mathrm{IU} / \mathrm{mL}$. Of the total 96 patients, 100\% were HBsAg positive, $88(91.7 \%)$ were HBeAg negative and 8 $(8.3 \%)$ were HBeAg positive. A significant correlation was found between the HBeAg serostatus, HBV DNA level and the histological activity index necroinflammatory total scores $(\mathrm{P}=0.034$ and 0.000$)$. We found no correlation between the fibrosis score and HBeAg status $(\mathrm{P}=0.451)$. However, a statistically significant difference was found between HBV DNA levels and stage of fibrosis $(\mathrm{P}=0.048)$. A significant relationship was found between the HBeAg status, HBV DNA level and ALT and AST levels $(\mathrm{P}=0.000,0.000,0.032,0.024)$. The HBeAg status of CHB patients should not affect the treatment response or need for long-term follow-up visits with repeat ALT and HBV DNA levels. However, chronic hepatitis patients who are negative for $\mathrm{HBeAg}$ may need different short-term follow-up.
\end{abstract}

Keywords: ALT, HBV DNA Level, HBeAg Status, Liver Histology

\section{Introduction}

Hepatitis B Virus (HBV) can cause chronic liver infection. This virus is responsible for more than 240 million cases of chronic infection and about 600,000 deaths each year worldwide. It is still a major public health problem in subSaharan Africa and East Asia [1]. Infection with HBV does not always lead to chronic hepatitis and $<5 \%$ of adults progress to chronic HBV infection [2]. Progression to longterm HBV infection occurs in approximately $15-40 \%$ of infected patients [3]. Chronic HBV infection may lead to cirrhosis, hepatocellular carcinoma [4], liver failure [3] and/or death [5]. Various factors seems to affect the natural course of hepatitis B infection including age, sex, immune status of the individual, viral load, replication of HBV and other factors [6]. The HBV is usually found in blood, saliva, semen, vaginal secretions, milk and urine [5]. Chronic HBV infection is usually the result of perinatal transmission, early childhood infection, contaminated blood transfusions, unprotected sexual contact or sharing of contaminated needles [7]. Chronic hepatitis is defined using clinicopathological criteria. In chronic hepatitis B infection, a necroinflammatory reaction is seen in the liver, patients have more than six months of clinical findings, and a change is seen in liver biochemical markers. The hallmark of the disease is a persistent rise in the serum aminotransferase levels (alanine aminotransferase, or ALT, is most sensitive) for at least 6 months [8]. The natural history of chronic hepatitis $\mathrm{B}(\mathrm{CHB})$ includes a $\mathrm{HBeAg}$ positive, immunetolerant phase that then progresses to a $\mathrm{HBeAg}$-positive, immune-reactive phase, $\mathrm{HBe} \mathrm{Ag}$-negative, inactive $\mathrm{HBV}$ carrier state, HBeAg-negative $\mathrm{CHB}$ phase and HBsAgnegative phase (occult infection) [9]. The HBV is a DNA virus and this virus is capable of genome organization, has a replication replication cycle, and affects the host immune response. The HBV can be detected serologically, by isolation of the virus, by detection/identification of HBV DNA polymerase activity and HBV DNA in the serum [10]. 
Histopathological changes that occur with $\mathrm{HBV}$ infection include necroinflammatory activity (inflammation and necrosis) and fibrosis, which are correlated with $\mathrm{HBeAg}$, anti-HBe, ALT, and HBV DNA levels [8, 11]. The guidelines recommend cutoff values of $40 \mathrm{IU} / \mathrm{ml}$ for alanine aminotransferase (ALT) levels and $2000 \mathrm{IU} / \mathrm{ml}$ for $\mathrm{HBV}$ DNA levels [12, 13]. A histologic activity index has been created which uses histological features to determine grade (inflammation) and stage (fibrosis) [8].

\section{Methods}

\subsection{Study Design}

This study was approved by the local Institutional Review Board.

In this retrospective study, all liver specimens were evaluated. The liver specimens were four micrometer thick formalin-fixed and paraffin-embedded sections created from liver biopsies of patients with chronic HBV infection. The specimens were stained with hematoxylin-eosin (H\&E), Masson's trichrome, reticulin silver stain and periodic acidSchiff (PAS) in the State Hospital's pathology laboratory between January 2009 and May 2014. In our study, all cases had a positive hepatitis B surface antigen for at least six months and all patients had not taken interferon or antiviral therapy prior to their liver biopsy.

\subsection{Liver Biopsy (Histopathologic Changes)}

All cases of chronic hepatitis B were categorized as periportal or periseptal interface hepatitis with piecemeal necrosis (score: 0-4), confluent necrosis (score: 0-6), focal (spotty) lytic necrosis, apoptosis and focal inflammation (score: 0-4), portal inflammation (score: 0-4). The necroinflammatory total scores (grade) were classified into four subcategories: minimal chronic hepatitis (scores 1-3), mild chronic hepatitis (scores 4-8), moderate chronic hepatitis (scores 9-12), and severe chronic hepatitis (scores 13-18). Staging was based on fibrosis, with scores ranging from 0 to 6 . The scoring system described by Ishak (modified Knodell) was used. Patients were divided into groups based on fibrosis scores (stage): those with scores $\leq 2$ were classified as mild fibrosis and those with scores 3-6 had advanced fibrosis $[14,15,16]$.

\subsection{Biochemical Tests; Alanine Aminotransferase (ALT or SGPT) and Aspartate Aminotransferase (AST or SGOT), Albumin, Alpha-Fetoprotein (AFP) Levels}

The cutoff value for serum ALT levels was $40 \mathrm{IU} / \mathrm{L}$ and was $35 \mathrm{IU} / \mathrm{L}$ for AST [12]. The upper limit of normal for serum AFP levels was $\leq 10 \mu \mathrm{g} / \mathrm{L}$ [17]. The normal range for serum albumin was 3.5-5.5 g/dl. A Cobas 8000 modular analyzer series (the COBAS c502, c701, Roche Diagnostics, Japan) was used to measure ALT, AST, albumin and AFP levels. On the other hand, it has been suggested that the cutoff values for serum ALT and AST should be $30 \mathrm{IU} / \mathrm{L}$ for men and $19 \mathrm{IU} / \mathrm{L}$ for women $[18,19]$.

\subsection{Serum HBV DNA Levels}

The HBV DNA was categorized based on level: $\leq 20,20$ $\leq 2000,2000-20,000$ and $\geq 20000 \quad \mathrm{IU} / \mathrm{mL} \quad(1 \mathrm{IU} / \mathrm{mL} \approx 5,82$ copies $/ \mathrm{mL}$ ). The lower limit of detection was $20 \mathrm{IU} / \mathrm{mL}$ and the upper limits of detection was $170000000 \mathrm{IU} / \mathrm{mL}$ (the quantitative range of this assay is 1.3-8.2 $\log \mathrm{IU} / \mathrm{mL}$ ). The Cobas Amplicor HBV Monitor test (real-time polymerase chain reaction, Roche Diagnostic Systems, COBAS ${ }^{\circledR}$ AmpliPrep ${ }^{\circledR}$ HBV Test, COBAS ${ }^{\circledR}$ TaqMan ${ }^{\circledR} 48$ ) was used in this study $[12,20,21]$.

\subsection{Hepatitis B Viral Markers}

The electrochemiluminescence immunoassay (ECLIA) was performed using the Cobas 6000 analyzer series (the Cobas e601 analyzer, Roche Diagnostics, Hitachi, Japan) in order to measure the hepatitis B surface antigen (anti-HBs), hepatitis B surface antigen (HBsAg), Hepatitis B e antigen (HBeAg) and hepatitis B e antibody (anti-HBe) levels.

\subsection{Statistical Analyses}

Data were analyzed using Statistical Package for Social Sciences (SPSS) software (version 21.0 for Windows, IBM Corp. Released 2012. IBM SPSS Statistics for Windows, Armonk, NY: IBM Corp.). The $t$-test was used to compare averages, a chi-square test was used to determine the dispersion of the two groups (HBeAg positive vs negative), and a Kruskal-Wallis-H test was used to determine the dispersion of $\mathrm{HBeAg}$ positive group and a $\mathrm{HBeAg}$ negative group. All differences associated with a chance probability of 0.05 or less were considered statistically significant. Continuous variables are presented as mean \pm standard deviation (SD).

\section{Results and Discussion}

Patient characteristics: A total of 96 chronic hepatitis B cases were examined. The mean age of the patients was $42.32 \pm 12.6$ years (range:16-79 years). There were 55 males and 41 female cases in this study. The clinical, histopathological, virological, biochemical data of the 96 chronic hepatitis B patients were shown in Table 1.

Liver biopsy; necroinflammatory activity and fibrosis: The mean total scores of the liver biopsy based on the Ishak modified Knodell histologic activity index for necroinflammatory activity (grade) and fibrosis (stage) were $6.01 \pm 2.46$ (range 2 to 13 ) and $1.6 \pm 0.99$ (range 0 to 5), respectively. Most patients had mild chronic hepatitis: $14.6 \%$ had scores ranging from 1 to 3,63 patients $(65.6 \%)$ had scores ranging from $4-8,18.8 \%$ had scores ranging from 9 to 12 , and $1 \%$ had a score in the $13-18$ range. The fibrosis (stage) scores were as follows: 81 patients $(84.4 \%)$ had mild fibrosis (score $0-2$ ) and 15 patients $(15.6 \%)$ had advanced fibrosis (scores 3-6).

Biochemical tests: The mean levels of ALT, AST, albumin 
and AFP were $32.6 \pm 21.0 \mathrm{IU} / \mathrm{L}$ (range 8 to $113 \mathrm{IU} / \mathrm{L}$ ), 25.6 $\pm 11.2 \mathrm{IU} / \mathrm{L}$ (range 12 to $84 \mathrm{IU} / \mathrm{L}$ ), $4.6 \pm 0.3$ (g/dL) (range 3.69 to $5.4 \mathrm{~g} / \mathrm{dL}$ ), and $3.4 \pm 2.8 \mu \mathrm{g} / \mathrm{L}$ (range 22 to $0.6 \mu \mathrm{g} / \mathrm{L}$ ), respectively. Low AST $(\leq 35 \mathrm{IU} / \mathrm{L})$ and ALT $(\leq 40 \mathrm{IU} / \mathrm{L})$ levels were detected in $86.5 \%$ and $76 \%$ of the cases, respectively. In all cases, the albumin level was in the normal range. Serum AFP levels were elevated $(>7 \mu \mathrm{g} / \mathrm{L})$ in only 8 patients $(8.3 \%)$.

Serum HBV DNA levels: The mean level of HBV DNA was $8952091.6 \pm 33829772.4 \mathrm{IU} / \mathrm{mL}$ (range 21 to 170 million $\mathrm{IU} / \mathrm{mL})$. In our study, 40 cases $(41.7 \%)$ had undetectable
(<20 IU/mL) levels of HBV DNA, 14 (14.6\%) had levels ranging from 21 to $2000 \mathrm{IU} / \mathrm{mL}, 22(22.9 \%)$ had levels ranging from 2001 to $20000 \mathrm{IU} / \mathrm{mL}$, and 20 (20.8\%) had levels $>20001 \mathrm{IU} / \mathrm{mL}$.

HbeAg and anti-HBeAg status: All patients were HBsAg positive in this study. However, 88 cases (91.7\%) were $\mathrm{HBeAg}$ negative and 8 cases $(8.3 \%)$ were $\mathrm{HBeAg}$ positive. In our study, 84 cases $(87.5 \%)$ were negative for anti-HBe and 12 cases $(12.5 \%)$ were positive for anti-HBe. The clinical, liver histology, biochemical, and virological data $\mathrm{HBeAg}$ Serostatus patients was shown in Table 2.

Table 1. Patients Characteristics, Histological Activity Scores, Serological and Biochemical data for Chronic Hepatitis B patients

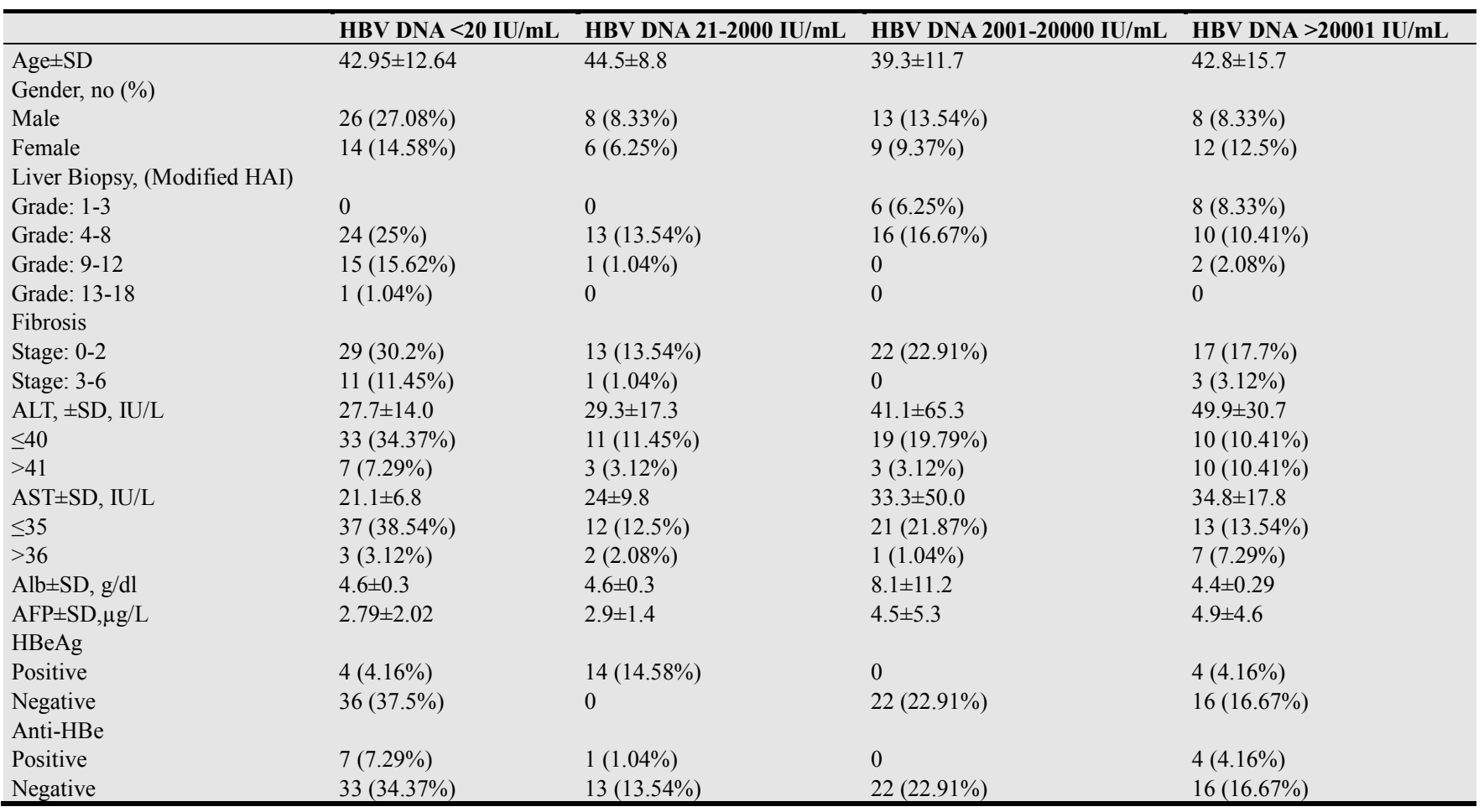

Table 2. HBeAg positive or negative distribution of patients with demographic, liver biochemical test and virological data

\begin{tabular}{lll}
\hline & HBeAg Positive & HBeAg Negative \\
\hline Age \pm SD & $41 \pm 18$ & $42 \pm 12$ \\
Gender & & $50(52.083 \%)$ \\
Male & $5(5.208 \%)$ & $38(39.583 \%)$ \\
Female & $3(3.125 \%)$ & $11(11.458 \%)$ \\
Liver Biopsy, (Modified HAI) & & $58(60.416 \%)$ \\
Grade: $1-3$ & $3(3.125 \%)$ & $18(18.75 \%)$ \\
Grade: $4-8$ & $3(3.125 \%)$ & $1(1.041 \%)$ \\
Grade: $9-12$ & 0 & \\
Grade: $13-18$ & 0 & $75(78.125 \%)$ \\
Fibrosis & & $13(13.541 \%)$ \\
Stage: $0-2$ & $6(6.25 \%)$ & $30 \pm 17$ \\
Stage: $3-6$ & $2(2.083 \%)$ & $24 \pm 8$ \\
ALT \pm SD, IU/L & $60 \pm 35$ & $2809015 \pm 18878661$ \\
AST \pm SD, IU/L & $40 \pm 23$ & \\
HBV DNA IU/mL & $31765474 \pm 62859151$ & \\
\hline
\end{tabular}

Correlation of liver histology with gender, ALT, AST and AFP levels: There was not a correlation between liver necroinflammatory total scores (grade) and gender, ALT, AST and AFP levels $(\mathrm{P}=0.601,0.344,0.380,0.368$, respectively). We found no significant difference in liver fibrosis with regards to gender, ALT, AST and AFP levels $(\mathrm{P}=$ $0.430,0.360,0.431,0.451$, respectively).

Relationship of liver histology with HBeAg status and serum HBV DNA levels: A significant relationship was found between the $\mathrm{HBeAg}$ serostatus and the histological activity 
index necroinflammatory total scores $(\mathrm{P}=0.034)$. The majority of patients who were $\mathrm{HBeAg}$ negative had a score of 4 to 8 . There was also a significant correlation between liver necroinflammatory total scores and the HBV DNA level $(\mathrm{P}=0.000)$. Our study showed that all patients with low or undetectable serum HBV DNA levels $(<20$ and 21-2000 $\mathrm{IU} / \mathrm{mL}$ ) had necroinflammatory total scores below eight. We found no correlation between the fibrosis score and the HBeAg status $(\mathrm{P}=0.451)$. However, a statistically significant relationship was seen between HBV DNA levels and fibrosis stage $(\mathrm{P}=0.048)$. In our study, 52 patients $(54.1 \%)$ had mild fibrosis (stage 0-2) and these patients also had a HBV DNA level of $\leq 2000 \mathrm{IU} / \mathrm{mL}$ (Figure 1A-B-C).

Correlation between HBeAg status, HBV DNA level and biochemical tests: No statistically significant relationship was found between $\mathrm{HBeAg}$ serostatus and HBV DNA level $(\mathrm{P}=0.508)$. A significant relationship was found between HBeAg status and ALT and AST levels $(\mathrm{P}=0.000,0.000)$. The HBeAg status was not correlated with the AFP level $(\mathrm{P}=$ 0.076). The serum HBV DNA level was significantly correlated with ALT and AST levels $(\mathrm{P}=0.032,0.024$, respectively). The HBV DNA level was not associated with the AFP level $(\mathrm{P}=0.202)$. About $80.6 \%$ of HbeAg negative patients had an ALT level of $\leq 40 \mathrm{IU} / \mathrm{L}$. Of the $88 \mathrm{HBeAg}$ negative patients, 80 had an AST level $\leq 35$ IU/L. Approximately $60.2 \%$ of patients with an ALT level of $\leq 40$ $\mathrm{IU} / \mathrm{L}$ also had a HBV DNA level $\leq 2000 \mathrm{IU} / \mathrm{mL}$.

Inactive chronic $H B V$ carriers: In our study, there were 88 patients with $\mathrm{HBeAg}$-negative chronic hepatitis B. Of these cases, HBeAg-negative had serum HBV DNA levels $\leq 2000$ $\mathrm{IU} / \mathrm{mL}$ and $43(40.3 \%)$ had normal serum ALT levels. Of these cases, $28(31.8 \%)$ had inflammatory activity total scores $\leq 8$ and 34 (37\%) had fibrosis scores $\leq 2$.

Chronic hepatitis $\mathrm{B}(\mathrm{CHB})$, found in about $2 \%$ of the population, is usually diagnosed after the hepatitis B surface antigen (HBsAg) has been positive for at least 6 months [22]. Liver biopsies are required to diagnosis chronic hepatitis B. Histologic changes (indicative of the degree of damage) have high prognostic value (predictive of progression to cirrhosis). When administering anti-viral medication, it is useful to obtain pre- and post-treatment biopsies to track response to treatment [14]. The immune reactive $\mathrm{HBeAg}$-positive phase is characterized by high levels of aminotransferases, $\mathrm{HBeAg}$ positivity, lower serum HBV DNA levels and moderate/severe histologic activity [13]. Patients who are inactive $\mathrm{HBV}$ carriers are $\mathrm{HBeAg}$ negative, anti-HBe positive, have normal ALT levels, minimal/no histological changes and fibrosis and undetectable/low levels of HBV DNA (serum HBV DNA $<2,000 \mathrm{IU} / \mathrm{ml}$ or $\leq 10000$ copies $/ \mathrm{mL}$ ) $[6,20,23]$. The purpose of treatment of chronic hepatitis $B$ is to prevent progression to end-stage liver disease, cirrhosis and hepatocellular carcinoma [20]. In order to be candidates for treatment, $\mathrm{CHB}$ patients usually have to be $\mathrm{HBeAg}$ positive and $\mathrm{HBeAg}$ negative [13].

Patients with CHB have elevated ALT levels, necroinflammatory activity on liver biopsy and active HBV replication [7]. One should be consider liver biopsy in chronic hepatitis B patients who are in one of the following groups: 1) HBeAg positive, HBV DNA $\geq 20,000 \mathrm{IU} / \mathrm{mL}$, minimally and persistently/intermittently elevated ALT, age $>40$ years, $\mathrm{HBeAg}$ seroconversion that does not occur spontaneously (3-6 months); 2) HBeAg negative, HBV DNA $\geq 2000 \mathrm{IU} / \mathrm{mL}$, minimally elevated ALT, age $>40$ years; 3 ) HBeAg negative, HBV DNA $\geq 2000 \mathrm{IU} / \mathrm{mL}$, minimally elevated ALT, age $>40$ years, ALT persistently/intermittently elevated [24].

The Gastroenterology Society of Australia recommends that $\mathrm{CHB}$ patients with HBV DNA levels > $2000 \mathrm{IU} / \mathrm{mL}$ receive treatment regardless of age due to the high risk for HBV-related HCC [25]. Chen CJ et al. reported that serum HBV DNA level $\geq 10,000$ copies $/ \mathrm{mL}$ is a major risk factor for hepatocellular carcinoma irrespective of $\mathrm{HBeAg}$ status, ALT level and the presence of cirrhosis [26]. The investigations on this subject are numerous, still perfect results have not been obtained. Nevertheless, the mortality rate is low today, owing to the contributions of the investigators. Studies differ with regards to the significance of histological parameters, biochemical tests, viral markers and viral load in $\mathrm{CHB}$ infection. In a previous study, Shao et al. reported that HBV DNA levels had no significant statistical association with liver histology regardless of HBeAg status [27]. In our study, we found that the necroinflammatory total scores were correlated with $\mathrm{HBeAg}$ status. However, a previous study by Alam et al. found that there were no associations between $\mathrm{HBV}$ DNA levels, necroinflammatory score and $\mathrm{HBeAg}$ status [28]. In our study, we found no correlation between the fibrosis score and $\mathrm{HBeAg}$ status. However, we did find a correlation between the HBV DNA levels and fibrosis stage. Madan et al. showed that HBV DNA levels correlated with liver histology (stage and grade) and levels of ALT [29] . Similarly, we found that patients with low or undetectable serum HBV DNA levels usually had a liver histological activity index score of less than 8 . This opinion has been supported by some authors. In another study by Peng et al., in HBeAg negative patients, high levels of HBV DNA had were positively correlated with the histological activity index (inflammatory and the fibrosis scores). In the same study, elevated HBV DNA levels were correlated with high ALT and ALT levels and with increased liver necroinflamatory processes regardless of patients $\mathrm{HBeAg}$ status [30]. Similarly, we found that the serum HBV DNA level was correlated with ALT and AST levels. Xiao et al. found a significant relationship between $\mathrm{HBeAg}$ positivity and elevated HBV DNA, but no associations were noted between liver histology (stage and grade), ALT levels and HbeAg status. In the same study, $\mathrm{HBeAg}$ status was not correlated with HBV DNA levels or degree of necroinflammation/fibrosis. Furthermore, the HBV DNA level was positively correlated with the degree of fibrosis in patients with normal ALT levels [31]. Similarly, we found no association between the fibrosis score and $\mathrm{HBeAg}$ status. Importantly, another study showed a correlation between the mean HBV DNA level and liver necroinflammatory score (grade). There was no correlation between HBV DNA level 
and liver fibrosis (grade), sex, age or HBeAg status. In addition, patients with serum HBV DNA $\geq 104$ copies/ml who needed a liver biopsy and were considering treatment were more likely to have higher a histologic activity index [32] . Zacharakis et al. reported that it is beneficial to follow HBV DNA levels in $\mathrm{CHB}$ patients who are $\mathrm{HBeAg}$ negative, as the HBV DNA levels correlate with the progression of hepatic damage [33] .

Martinot-Peignoux and colleagues examined the inactive HBsAg carrier state and found that the average serum HBV DNA level was 1300 copies/ml and that all patients had a necroinflammatory total score less than seven (consistent with mild chronic hepatitis) [34]. In our work, all patients with low serum HBV DNA levels $(<2000 \mathrm{IU} / \mathrm{mL})$ had necroinflammatory total scores less than 8 . All patients were $82(85.4 \%)$ cases with a necroinflammatory total scores, grade $\geq 4$, and had 15 cases $(15.6 \%)$ with a fibrosis, stage $\geq 3$. In our study, of the patients with $\mathrm{HBeAg}$ negative $\mathrm{CHB}$ infection, 10 (11.4\%) had HBV DNA >105 copies/Ml (mean: $2809015 \mathrm{IU} / \mathrm{Ml}, \approx 1.6 \times 107$ copies $/ \mathrm{mL}), 7(7.8 \%)$ had a staging score $\geq 4$ and $9(10.2 \%)$ had a grade score $\leq 2$. Inactive chronic HBV carriers have a good prognosis [23]. In our study, $40.3 \%(43 / 88)$ of $\mathrm{HBeAg}$ negative CHB patients had HBV DNA levels $\leq 2000 \mathrm{IU} / \mathrm{mL}$ and normal serum ALT levels. These results are consistent with a previous study in which $31.8 \%$ of $\mathrm{HBeAg}$ negative $\mathrm{CHB}$ patients had inflammatory activity total scores $\leq 8$. Mild hepatic fibrosis was present in $38.6 \%$ (34 of 88 ) patients in our study. $\mathrm{HBeAg}$ negative $\mathrm{CHB}$ patients were more likely to have lower HBV DNA levels and less necroinflammatory changes, but there was no relationship between fibrosis and ALT levels $(\mathrm{P}=$ $0.025,0.000$ and 0.714 , respectively). Papatheodoridis et al. reported that the usefulness of treatment in patients with minimal necroinflammatory changes is uncertain [35]. However, the study by Kim et al. recommended anti-viral therapy in HbeAg negative $\mathrm{CHB}$ because spontaneous regression is unusual and the course of the disease is worse without therapy [11]. Saikia et al. suggested that treatment should be initiated in patients with higher ALT levels, high HBV DNA levels and active necroinflammation on liver biopsy regardless of HbeAg status. Furthermore, it should be noted that no correlation has been seen between histological activity and normal ALT levels [36] .

Some authors have reported that HBV DNA levels fluctuate over time in CHB patients [27, 37, 38]. Inactive chronic HBV carriers (HBeAg-negative) are particularly only do not assume the serum in monitoring the course of the patient cutoff serum HBV DNA levels. The serum levels of HBV DNA have been not used as an indicator of changes in $\mathrm{HBeAg}$ levels [37]. In some $\mathrm{HBeAg-negative} \mathrm{cases,} \mathrm{there} \mathrm{is}$ increase in serum HBV DNA and normal ALT levels [38]. In addition, spontaneous seroconversion from $\mathrm{HBeAg}$ to anti$\mathrm{HBe}$ does not occur in all cases [39]. Whereas, there are unfortunately many exceptions. The rate of spontaneous $\mathrm{HBeAg}$ seroconversion is low in untreated patients and occurs in $8-15 \%$ of patients in Central Europa and USA and $<2 \%$ of pediatric patients in Asia [40]. This is an extremely important point.

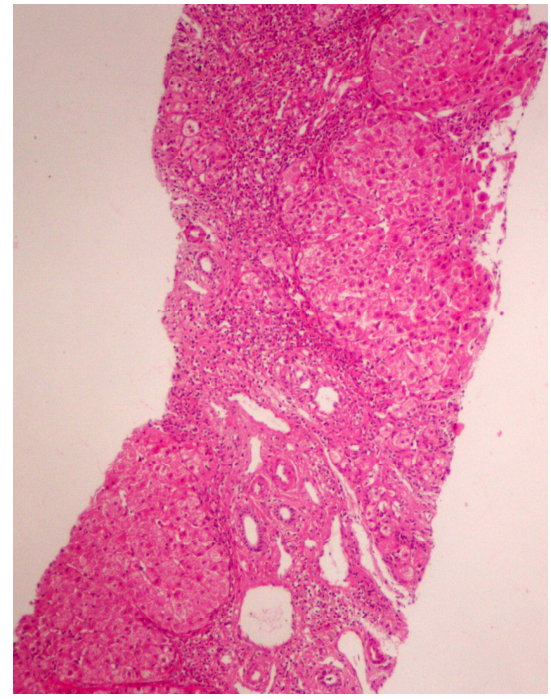

A

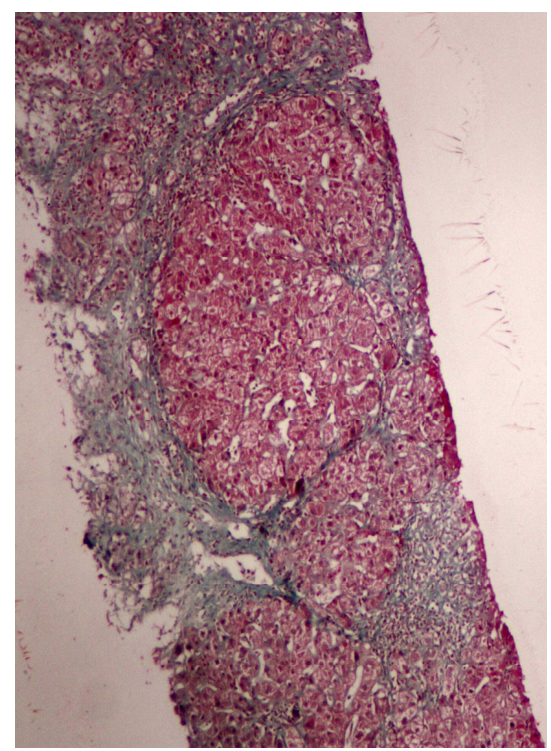

B

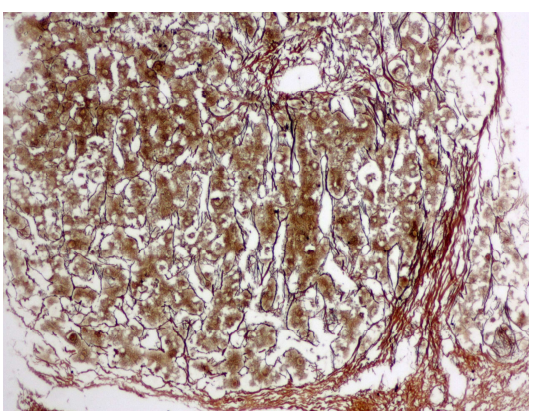

C

Figure 1. Chronic hepatitis, HbeAg negative. A-portal/periportal inflammation (Hematoxylin-Eosin, original magnification $\times 40$ objective). $B$ Masson trichrome stain,dense staining of collagen fibersorfibrous septa (advanced fibrosis, original magnification $\times 40$ objective). C-Reticulin stain, reticulin network and nodular architecture (original magnification $\times 200$ objective). Patient: 45-year-old-female, HBeAg, positive; HBV DNA, $8.2 x$ $10^{(7)} \mathrm{IU} / \mathrm{mL} ; A L T, 100 \mathrm{IU} / \mathrm{L} ; \mathrm{SGOT}, 84 \mathrm{IU} / \mathrm{L}$. 


\section{Conclusion}

In conclusion, Chronic hepatitis B has specific clinical and histological behavior and increases the risk of end-stage liver disease/cirrhosis and HCC. The course of HBeAg-negative chronic hepatitis is not available to markers only cutoff HBV DNA. Treatment decisions, including whether to perform a liver biopsy, are important. HBV DNA levels were correlated with the liver necroinflammatory activity index, fibrosis stage and serum ALT, AST levels in this study. However the HBV DNA level was not correlated with the $\mathrm{HBeAg}$ serostatus. A significant relationship was found between the $\mathrm{HBeAg}$ status and liver histological inflammatory scores. The HBeAg status of CHB patients should not affect the treatment response or need for long-term follow-up visits with repeat ALT and HBV DNA levels. However, chronic hepatitis patients who are negative for HBeAg may need different short-term follow-up. In order to more effectively manage the disease and decide on treatment, $\mathrm{HBeAg}$ negative chronic hepatitis $B$ patients should be referred for a liver biopsy.

\section{List of Abbreviations Used}

HBV, Hepatitis B Virus; HCC, Hepatocellular carcinoma; ALT, Alanine aminotransferase, AST, Aspartate aminotransferase; Alb, Albumin; AFP, Alpha-fetoprotein; CHB, Chronic hepatitis B; HBsAg, Hepatitis B surface antigen; anti-HBs, hepatitis $B$ surface antigen; $\mathrm{HBeAg}$, Hepatitis B e antigen; anti-HBe, hepatitis B e antibody

\section{Acknowledgements}

Written informed consent was obtained from the patient for the publication of this report and any accompanying images.

\section{References}

[1] World Health Organization: WHO: Hepatitis B. Fact Sheet No. 204. (http://www.who.int/mediacentre/factsheets/fs204/en/) (accessed 4 May 2014).

[2] Sorrell MF, Belongia EA, Costa J, Gareen IF, Grem JL, Inadomi JM, Kern ER, McHugh JA, Petersen GM, Rein MF, Strader DB, Trotter HT: National Institutes of Health consensus development conference statement: management of hepatitis B. Hepatology. 2009; 49(5 Suppl):S4-S12. doi: 10.1002/hep.22946.

[3] Lok AS: Chronic hepatitis B. N Engl J Med. 2002; 346(22):1682-3.

[4] Lee WM: Hepatitis B virus infection. N Engl J Med. 1997; 337(24):1733-45.

[5] Lavanchy D: Hepatitis B virus epidemiology, disease burden, treatment, and current and emerging prevention and control measures. J Viral Hepat. 2004; 11(2):97-107.

[6] Sharma SK, Saini N, Chwla Y: Hepatitis B virus: inactive carriers. Virol J. 2005; 2:82.

[7] Martinelli D, Fortunato F, Simsek G, Prato R: Epidemiology and Prevention of Viral Hepatitis B and C. Practical Management of Chronic Viral Hepatitis. Edited by Serviddio G. Croatia: In Tech; 2013;3-18.

[8] Geller SA, Petrovic LM: Chronic Hepatitis (Chronic Necroinflammatory Disease of the Liver)-Grading and Staging. Biopsy Interpretation of the Liver. 2nd edition. Philadelphia: Lippincott Williams \& Wilkins; 2009;97-120

[9] Squadrito G, Spinella R, Raimondo G: The clinical significance of occult HBV infection. Ann Gastroenterol. 2014; 27(1):15-19.

[10] Yim HJ, Lok AS: Natural history of chronic hepatitis B virus infection: what we knew in 1981 and what we know in 2005 . Hepatology. 2006; 43(2 Suppl 1):S173-81.

[11] Kim ES, Seo YS, Keum B, Kim JH, A H, Yim HJ, Kim YS, Jeen YT, Lee HS, Chun HJ, Um SH, Duck Kim C, Ryu HS: The HBV DNA cutoff value for discriminating patients with HBeAgnegative chronic hepatitis B from inactive carriers. Hepat Mon. 2011; 11(5):351-7.

[12] Ijaz B, Ahmad W, Javed FT, Gull S, Hassan S: Revised cutoff values of ALT and HBV DNA level can better differentiate $\mathrm{HBeAg}(-)$ chronic inactive HBV patients from active carriers. Virol J. 2011; 8: 86.

[13] European Association For The Study Of The Liver: EASL clinical practice guidelines: Management of chronic hepatitis B virus infection. J Hepatol. 2012; 57(1):167-85.

[14] Theise ND. Liver biopsy assessment in chronic viral hepatitis: a personal, practical approach. Mod Pathol. 2007; 20 Suppl 1:S3-14.

[15] Gara N, Zhao X, Kleiner DE, Liang TJ, Hoofnagle JH, Ghany MG: Discordance among transient elastography, aspartate aminotransferase to platelet ratio index, and histologic assessments of liver fibrosis in patients with chronic hepatitis C. Clin Gastroenterol Hepatol. 2013; 11(3):303-8.e1.

[16] Christensen C, Bruden D, Livingston S, Deubner H, Homan C, Smith K, Oh E, Gretch D, Williams J, McMahon B: Diagnostic accuracy of a fibrosis serum panel (FIBROSpect II) compared with Knodell and Ishak liver biopsy scores in chronic hepatitis C patients. J Viral Hepat. 2006; 13(10):652-8.

[17] Akuta N, Suzuki F, Kobayashi M, Hara T, Sezaki H, Suzuki Y, Hosaka T, Kobayashi M, Saitoh S, Ikeda K, Kumada H: Correlation between hepatitis B virus surface antigen level and alpha-fetoprotein in patients free of hepatocellular carcinoma or severe hepatitis. J Med Virol. 2014; 86(1):131-8.

[18] Keeffe EB, Dieterich DT, Han SH, Jacobson IM, Martin P, Schiff ER, Tobias H: A treatment algorithm for the management of chronic hepatitis B virus infection in the United States: 2008 update. Clin Gastroenterol Hepatol. 2008; 6(12):1315-41.

[19] Prati D, Taioli E, Zanella A, Della Torre E, Butelli S, Del Vecchio E, Vianello L, Zanuso F, Mozzi F, Milani S, Conte D, Colombo M, Sirchia G: Updated definitions of healthy ranges for serum alanine aminotransferase levels. Ann Intern Med. 2002; 137(1):1-10.

[20] Lok AS, McMahon BJ: Chronic hepatitis B. Hepatology. 2007; 45:507-39. 
[21] Keshvari M, Alavian SM, Sharafi H: How can we make decision for patients with chronic hepatitis $\mathrm{B}$ according to hepatitis B virus (HBV) DNA level? Hepat Mon. 2014; 5:e15285.

[22] McMahon BJ: Chronic hepatitis B virus infection. Med Clin North Am 2014, 98:39-54.

[23] Tong MJ, Trieu J: Hepatitis B inactive carriers: clinical course and outcomes. J Dig Dis. 2013; 14(6):311-7

[24] Gastroenterological Society of Australia and Digestive Health Foundation: Australian and New Zealand chronic hepatitis B (CHB) recommendations. Clinical update [webpage on the Internet] Victoria, Australia: The Digestive Health Foundation; 2008. Available from: http://www.gesa.org.au/files/editor_upload/File/Professional/C HB.pdf. Accessed May 5, 2014. http://www.nzsg.org.nz/uploads/Documents/HepBClinical.pdf

[25] Robotin M, Patton Y, Kansil M, Penman A, George J. Cost of treating chronic hepatitis B: comparison of current treatment guidelines. World J Gastroenterol. 2012; 18(42):6106-13.

[26] Chen CJ, Yang HI, Su J, Jen CL, You SL, Lu SN, Huang GT, Iloeje UH, REVEAL-HBV Study Group: Risk of hepatocellular carcinoma across a biological gradient of serum hepatitis B virus DNA level. JAMA. 2006; 295(1):65-73.

[27] Shao J, Wei L, Wang H, Sun Y, Zhang LF, Li J, Dong JQ: Relationship between hepatitis B virus DNA levels and liver histology in patients with chronic hepatitis B. World J Gastroenterol. 2007; 13(14):2104-7.

[28] Alam S, Ahamd N, Alam K, Mostafa G, Khan M: Correlation between Hepatitis B Viral DNA Load and Extent of Liver Pathology in Patients with Chronic Hepatitis B. Hepatitis Monthly. 2008, 8(3):185-9

[29] Madan K, Batra Y, Jha JK, Kumar S, Kalra N, Paul SB, Singh R, Duttagupta S, Panda SK, Acharya SK: Clinical relevance of HBV DNA load in patients with chronic hepatitis B infection.Trop Gastroenterol. 2008; 29(2):84-90.

[30] Peng J, Luo K, Zhu Y, Guo Y, Zhang L, Hou J: Clinical and histological characteristics of chronic hepatitis $\mathrm{B}$ with negative hepatitis B e-antigen. Chin Med J (Engl). 2003; 116(9):1312-7.

[31] Xiao L, Xian J, Li Y, Geng A, Yang X, Han L, Xu H:
Parameters associated with significant liver histological changes in patients with chronic hepatitis B. ISRN Gastroenterol. 2014;2014:913890. doi: 10.1155/2014/913890. eCollection 2014.

[32] Mansour-Ghanaei F, Rafiei R, Joukar F, Naghipour M, Besharati S, Aminian K, Atrkar-Roushan Z: Relationship between serum HBV DNA level and liver histology in HBV carriers with normal ALT in Guilan province, Iran. Med Sci Monit. 2010; 16(3):BR97-101.

[33] Zacharakis G, Koskinas J, Kotsiou S, Tzara F, Vafeiadis N, Papoutselis M, Maltezos E, Sivridis E, Papoutselis K: The role of serial measurement of serum HBV DNA levels in patients with chronic $\mathrm{HBeAg}(-)$ hepatitis B infection: association with liver disease progression. A prospective cohort study. J Hepatol. 2008; 49(6):884-91.

[34] Martinot-Peignoux M, Boyer N, Colombat M, Akremi R, Pham BN, Ollivier S, Castelnau C, Valla D, Degott C, Marcellin P: Serum hepatitis B virus DNA levels and liver histology in inactive HBsAg carriers. J Hepatol. 2002; 36(4):543-6.

[35] Papatheodoridis GV, Manolakopoulos S, Liaw YF, Lok A: Follow-up and indications for liver biopsy in HBeAg-negative chronic hepatitis B virus infection with persistently normal ALT: a systematic review. J Hepatol. 2012;57(1):196-202.

[36] Saikia N, Talukdar R, Mazumder S, Khanna S, Tandon R: Management of patients with $\mathrm{HBeAg-negative} \mathrm{chronic}$ hepatitis B. Postgrad Med J. 2007; 83(975):32-9.

[37] Chu CJ, Hussain M, Lok AS: Quantitative serum HBV DNA levels during different stages of chronic hepatitis B infection. Hepatology. 2002; 36(6):1408-15.

[38] Chan HL, Wong ML, Hui AY, Hung LC, Chan FK, Sung JJ: Use of hepatitis B virus DNA quantitation to predict hepatitis $\mathrm{B}$ e antigen reversion in cases of chronic hepatitis B. J Clin Microbiol. 2003; 41(10):4793-5.

[39] Lok AS, Heathcote EJ, Hoofnagle JH: Management of hepatitis B: 2000-summary of a workshop. Gastroenterology. 2001; 120(7):1828-53.

[40] Dancygier H: Hepatitis B. Clinical Hepatology: Principles and Practice of Hepatobiliary Diseases. Volume 2. Edited by Dancygier H. Berlin Heidelberg: Springer; 2010:743-80 